\title{
Adnexal torsion - can laparoscopy wait?
}

\author{
Skręt przydatków - czy laparoskopia może poczekać? \\ Bartosz Cichoń1 (D), Łukasz Słowik¹, Katarzyna Baran', Aleksandra Gadomska1', Justyna Gilewska1, Tomasz Cichoń2, \\ Magdalena A. Lemm (D), Igor Bakon ${ }^{1}$ (D), Andrzej Witek ${ }^{1}$ \\ ${ }^{1}$ Katedra i Klinika Ginekologii i Położnictwa, Wydział Nauk Medycznych w Katowicach, \\ Śląsi Uniwersytet Medyczny w Katowicach \\ ${ }^{2}$ Wydział Lekarski, Uniwersytet Jagielloński - Collegium Medicum
}

\begin{abstract}
Adnexal torsion is a rare emergency condition and its diagnosis is challenging as the clinical presentation is nonspecific. About half of the cases of adnexal torsion are not identified in a timely manner. It is important to undergo prompt surgery to preserve ovarian function. Our article describes the clinical presentation of adnexal torsion and early surgical intervention to preserve the adnexa in a young woman.
\end{abstract}

\section{KEY WORDS}

adnexal torsion, ovaries, laparoscopy

\section{STRESZCZENIE}

Skręt przydatków jest rzadkim stanem nagłym, a jego diagnoza jest wyzwaniem, ponieważ objawy kliniczne są niecharakterystyczne. Około połowy przypadków skrętu przydatków pozostaje nierozpoznana w odpowiednim czasie. Podjęcie szybkiego leczenia operacyjnego jest istotne, aby zachować funkcję jajnika. W artykule opisano objawy kliniczne skrętu przydatków i wczesną interwencję chirurgiczną pozwalającą na zachowanie przydatków u młodej pacjentki.

SŁOWA KLUCZOWE

skręt przydatków, jajnik, laparoskopia

Received: $02.07 .2019 \quad$ Revised: 04.12.2019 $\quad$ Accepted: 07.09.2020 Published online: 28.02 .2021
Address for correspondence: dr n. med. Magdalena Agata Lemm, Katedra i Klinika Ginekologii i Położnictwa, Wydział Nauk Medycznych w Katowicach,
Ślaski Uniwersytet Medyczny w Katowicach, ul. Medyków 14, 40-752 Katowice, Polska, tel. +48 32 789 47 31, e-mail: ginekologia@sum.edu.pl

Copyright @ Śląski Uniwersytet Medyczny w Katowicach www.annales.sum.edu.pl 
A 17-year-old female patient was brought to the Gynaecology and Obstetrics Department Admission Room by Emergency Medical Services (EMS) because of severe abdominal pain in the right lower quadrant lasting for about 3 hours. In addition, she had been experiencing intense nausea for two hours. It was the 6th day of her menstrual cycle; the patient menstruates regularly. She had never had a gynaecological examination before. She did not report any difficulties with micturating or defecating. She did not report having any allergies, illnesses or taking medications. In childhood, she underwent tonsillectomy and appendectomy.

Arterial pressure at admission: $127 / 78 \mathrm{mmHg}$, heart rate: 115 beats/minute, body temperature 38.2 degrees Celsius. During the gynaecological examination, vaginal speculum did not reveal any signs of genital bleeding or discharge. The right lower quadrant showed tenderness to palpation; the view of the right adnexa revealed the presence of a mobile tumour; left adnexa with no abnormalities. With time the pain intensified leading to vomiting.

Ultrasound examination revealed a normal uterine body size: 49 × $37 \mathrm{~mm}$, endometrium thickness: $5 \mathrm{~mm}$, right ovary: volume: $42.6 \mathrm{ml}$, with a thin-walled cyst of 55 x $48 \mathrm{~mm}$, with a marked decrease in peripheral vascular resistance; left ovary: volume: $2.7 \mathrm{ml}$, with several small follicles up to $8 \mathrm{~mm}$. Normal results of laboratory tests, $\beta$ hCG concentration below $0.1 \mathrm{mIU} / \mathrm{ml}$; normal abdominal ultrasound. The patient was admitted to the Gynaecology and Obstetrics Department.

The differential diagnosis was carried out smoothly in the Department. Urinary diseases such as infection and calculi of the urinary system were excluded - the results of general urinalysis were normal. Due to the appendectomy in childhood and normal appearance of abdominal organs on imaging, gastrointestinal diseases were also excluded.

The patient was scheduled for laparoscopy. Examination showed a single rotation of the right adnexa around the ligament pedicle and the mesovarium. The ovary was bluish brown. The uterus, the left ovary, and fallopian tube were normal. The right adnexa were untwisted, and then the cyst was peeled off. The patient's status improved post-surgery; nausea and vomiting subsided. The patient was discharged on the second day after surgery in overall good condition.

Approximately $7 \%$ of acute abdominal pain is caused by adnexal torsion, i.e. a situation in which the ovary and fallopian tube rotate around the vascular pedicle and the mesovarium, leading to ischaemia due to blood vessel clamping. Venous and lymphatic stasis leads to haemorrhages and impaired arterial inflow with necrosis $[1,2]$. The longer the time after the symptoms appear, the more likely it is that the adnexa will need to be removed. If left untreated, abscesses, peritonitis, adhesions, infertility, or sepsis may develop [2]. It most often occurs in reproductive-age women. The conditions predisposing to ovarian torsion are anatomical abnormalities, increased ovarian volume and lesions in the fallopian tube. Half of the cases of ovarian torsion are related to the presence of a pathological mass in the ovaries, which contributes to their displacement. Ovarian malignancies are the cause of $2 \%$ of ovarian torsion. Ovarian torsion is usually unilateral and more often occurs on the right side (more space predisposes to rotation) [3].

Typical symptoms include acute or subacute abdominal pain in the lesser pelvis (often radiating to the lumbar region and groin), which intensifies with palpation. Peritoneal symptoms, including nausea, vomiting and increased body temperature, are often present. In severe cases, symptoms of shock may also occur. In addition to the typical clinical features, ovarian torsion may present with recurrent pain, which, after some time, becomes continuous (due to cutting off the blood supply to the ovary) [3].

The imaging study of choice when this disorder is suspected is Doppler ultrasonography $[4,5]$. The symptoms of ischaemia suggesting torsion include ovarian hyperaemia, central hyperechogenicity indicating oedema and dilated (up to $25 \mathrm{~mm}$ in diameter) follicles in the ovarian periphery [6]. In some cases, a cyst or hyperplasia that led to the torsion can be seen. The so-called whirlpool sign is typically observed in twisted vascular pedicle cases $[7,8]$. Evaluation of the pedicle using colour Doppler ultrasound allows the viability of the ovarian tissue to be assessed. The torsion is also indicated by the rotation of the adnexa to the contralateral side of the pelvis. The presence of a mass in the adnexal region or ovarian enlargement over $50 \mathrm{~mm}$ on computed tomography imaging may indicate adnexal torsion. The lesions may be accompanied by tilting of the uterus to the affected side. However, the sensitivity of CT in this condition is lower than that of ultrasound [3]. There are no characteristic changes in laboratory test results [2]. The diagnosis of ovarian torsion is usually based on excluding other causes of lower abdomen pain [9]. Differential diagnosis should take into account ectopic pregnancy, ovarian cyst rupture, acute adnexitis, torsion of pedunculated uterine leiomyoma, ovarian hyperstimulation syndrome, acute appendicitis, gastritis, inflammation of the gastric and intestinal mucosa, inflammatory bowel diseases, diverticulitis, bowel obstruction, pyelonephritis, urolithiasis and cystitis [10].

The procedure of choice is laparoscopic surgery, which is associated with a shorter hospital stay and fewer complications [11]. An attempt should be made to preserve the ovary. First, the adnexa should be untwisted, and then the lesions should be extirpated together with the capsule. Tumour removal reduces the recurrence rate by about $75 \%$ [12]. If no pathology is revealed, ovariopexy may be considered $[2,12,13]$.

Ovarian torsion is a gynaecological emergency that is difficult to diagnose (in $45 \%$ of Doppler ultrasound cases the flows are normal), and treat and requires immediate intervention. Fast diagnosis of ovarian torsion gives a chance to save the adnexa and preserve fertility $[12,14]$. 


\section{Author's contribution}

Study design - M. Lemm, B. Cichoń

Manuscript preparation - T. Cichoń, Ł. Słowik

Literature research - K. Baran, A. Gadomska, J. Gilewska

Final approval of the version to be published -A. Witek, I. Bakon

\section{REFERENCES}

1. Nizar K., Deutsch M., Filmer S., Weizman B., Beloosesky R., Weiner Z Doppler studies of the ovarian venous blood flow in the diagnosis of adnexal torsion. J. Clin. Ultrasound 2009; 37(8): 436-439, doi: 10.1002/jcu.20621. 2. Górecki W. Skręt jajnika u dzieci. Med. Prakt. Chirurgia 2014; 2: 79-89. 3. A. Zawadzka. Skręt przydatków lub guza przydatków. W: Stany nagłe położnictwo i ginekologia. Red. R. Dębski. Wyd. Medical Tribune Polska. Warszawa 2012, s. 221-225

4. Ciebiera M., Słabuszewska-Jóźwiak A., Jakiel G. Laparoskopowe, zachowawcze leczenie operacyjne skrętu przydatków u kobiety w wieku rozrodczym. Post. Nauk Med. 2014; 8: 559-562.

5. Bar-On S., Mashiach R., Stockheim D., Soriano D., Goldenberg M., Schiff E., Seidman D.S. Emergency laparoscopy for suspected ovarian torsion: are we too hasty to operate? Fertil. Steril. 2010; 93(6): 2012-2015, doi: 10.1016/j. fertnstert.2008.12.022.

6. Kiechl-Kohlendorfer U., Maurer K., Unsinn K.M. Gassner I. Fluid-debris level in follicular cysts: a pathognomonic sign of ovarian torsion. Pediatr. Radiol 2006; 36(5): 421-425, doi: 10.1007/s00247-005-0104-z.

7. Vijayaraghavan S.B. Sonographic whirlpool sign in ovarian torsion. J. Ultrasound Med. 2004; 23(12): 1643-1649, doi: 10.7863/jum.2004.23.12.1643.

8. Valsky D.V., Esh-Broder E., Cohen S.M., Lipschuetz M., Yagel S. Added value of the gray-scale whirlpool sign in the diagnosis of adnexal torsion. Ultrasound Obstet. Gynecol. 2010; 36(5): 630-634, doi: 10.1002/uog.7732.
9. Nair S., Joy S., Nayar J. Five year rertospective case series of adnexal torsion. J. Clin. Diagn. Res. 2014: 8(12): OC09-OC13, doi: 10.7860/ JCDR/2014/9464.5251

10. J. Świder-Musielak. Ostry jednostronny ból w podbrzuszu i płyn w jamie otrzewnej u 24-letniej pacjentki. W: Sytuacje kliniczne w ginekologii, onkologii ginekologicznej i uroginekologii. Red. G.H. Bręborowicz, E. Nowak-Markwitz E., T. Rechberger. Wyd. Lekarskie PZWL. Warszawa 2017, s. 250-259.

11. Lo L.M., Chang S.D., Horng S.G., Yang T.Y., Lee C.L., Liang C.C. Laparoscopy versus laparotomy for surgical intervention of ovarian torsion. J. Obstet. Gynaecol. Res. 2008; 34(6): 1020-1025, doi: 10.1111/j.1447-0756.2008.00806.x 12. Tsafrir Z., Hasson J., Levin I., Solomon E., Lessing J.B., Azem F. Adnexal torsion: cystectomy and ovarian fixation are equally important in preventing recurrence. Eur. J. Obstet. Gynecol. Reprod. Biol. 2012; 162(2): 203-205, doi: 10.1016/j.ejogrb.2012.02.027

13. Weitzman V.N., DiLuigi A.J., Maier D.B., Nulsen J.C. Prevention of recurrent adnexal torsion. Fertil. Steril. 2008; 90(5): 2018.e1-3, doi: 10.1016/j. fertnstert.2008.02.144

14. Oelsner G., Shashar D. Adnexal torsion. Clin. Obstet. Gynecol. 2006; 49(3): 459-463, doi: 10.1097/00003081-200609000-00006. 